\title{
PERI-OPERATIVE SYNTOCINON INFUSION IN LSCS
}

\author{
V. Ezhil Rajan'1, Ranjith Kumar $S^{2}$ V. Gopu ${ }^{3}$
}

1 Professor, Department of Anaesthesiology, Aarupadai Veedu Medical College and Hospital, Puducherry, India. ${ }^{2}$ Assistant Professor, Department of Anaesthesiology, Aarupadai Veedu Medical College and Hospital, Puducherry, India. ${ }^{3}$ Senior Resident, Department of Anaesthesiology, Aarupadai Veedu Medical College and Hospital, Puducherry, India.

\section{BACKGROUND}

ABSTRACT

Oxytocin for the purposes of augmentation and induction of labour is one of the most frequently used medications in obstetrics. Recent studies show that oxytocin is used in over $50 \%$ of labouring women in some hospitals. Yet, there is tremendous variability in the dose and dosing interval in clinical practice.

The objective of this study was to evaluate peri-operative usage of syntocinon for all LSCS patients to augment better uterine contractions, and for minimising peri operative morbidity and mortality.

\section{MATERIALS AND METHODS}

200 patients of ASA grade I \& II in the age group 20-35 years scheduled for both elective \& emergency LSCS surgeries were divided randomly in two groups, Group NSI (Control) and Group SI (Test). $100 \mathrm{ml}$ NS with 2 units of syntocinon was added and infusion was continued at the rate of 30 to 50 drops per minute, immediately after performing subarachnoid block in the test group. At 1 min, $2 \mathrm{~min}, 3 \mathrm{~min}, 5 \mathrm{~min}$, parameters like heart rate, saturation, blood pressure, uterine tonicity and newborn APGAR score were recorded \& compared with control group.

\section{RESULTS}

Both the groups were comparable in terms of Age \& Parity. In terms of uterine tonicity, usage of vasopressor/ glycopyrrolate, blood loss \& perioperative HCT, the p-value is $<0.00001 \&$ results are significant in test group in comparison with control group.

\section{CONCLUSION}

With this study we conclude that perioperative syntocinon infusion of 2 units in $100 \mathrm{ml}$ NS (before the uterine incision and delivery of the baby) as a priming technique was found to be more beneficial in maintaining haemodynamic stability, good uterine contractions, minimal uterine blood loss, without alteration in APGAR scoring is noted.

\section{KEY WORDS}

Oxytocin, Blood Loss, Uterine Tone, APGAR.

HOW TO CITE THIS ARTICLE: Rajan VE, Kumar RS, Gopu V. Peri-operative syntocinon infusion in LSCS. J. Evolution Med. Dent. Sci. 2018;7(52):5488-5491, DOI: 10.14260/jemds/2018/1214

\section{BACKGROUND}

Oxytocin for the purposes of augmentation and induction of labour is one of the most frequently used medications in obstetrics $^{1}$. Recent studies show that oxytocin ${ }^{2,3}$ is used in over $50 \%$ of labouring women in some hospitals. Yet, there is tremendous variability in the dose and dosing interval in clinical practice.

\section{Aims and Objectives-}

1. To study the effects of syntocinon infusion before delivery with regard to

- Perioperative hypotension.

- Intra operative blood loss.

- Post-partum bleeding.

- Neonatal outcome.

2. To compare effects of syntocinon infusion in perioperative period (before delivery of baby) versus without syntocinon infusion for LSCS surgeries under subarachnoid block.

'Financial or Other Competing Interest': None.

Submission 10-10-2018, Peer Review 06-12-2018,

Acceptance 12-12-2018, Published 24-12-2018.

Corresponding Author:

Dr. Ranjith Kumar $S$,

Assistant Professor, Department of Anaesthesiology,

Aarupadai Veedu Medical College and Hospital,

Puducherry, India.

E-mail:ranjit9124@gmail.com

DOI: $10.14260 / j e m d s / 2018 / 1214$

\section{(c) (1) $(9)$}

\section{MATERIALS AND METHODS}

The present double blinded randomized controlled trial study which was carried out in the Department of Anaesthesiology, A.V.M.C \& H, Puducherry after obtaining approval from ethics committee. The study was done on 200 patients of ASA grade I \& II with age group 20-35 years scheduled for both elective \& emergency LSCS surgeries. This sample size was taken for convenience.

\section{Exclusion Criteria}

- Known history of sensitivity to bupivacaine.

- Non-acceptance by patient.

- Body weight $>110 \mathrm{~kg}$ and $<45 \mathrm{~kg}$ and height $<145 \mathrm{~cm}$.

- Peripheral or central neurological disease raised intracranial tension, valvular heart diseases, significant ECG changes, renal disease, endocrinal disease, metabolic disease, hepatic disease, coagulopathy and bleeding disorders.

- History of spinal cord surgery, vertebral deformities, infection at site of block.

\section{Consent}

Details of procedure were explained to all the patients during PAC and an informed consent was obtained.

\section{Patient Grouping}

Patients were blinded by sealed envelope technique and observer anaesthesiologist was kept unaware of which drug 
was infused to which patient thus avoiding observer bias. The anaesthesiologist who performed the spinal anaesthesia and who infuse study drug took no further part in the study.

Selected 200 patients were divided randomly in to two groups depending upon the drug given

\begin{tabular}{|c|c|}
\hline $\begin{array}{c}\text { Group NSI } \\
(\mathrm{n}=100) \\
\text { (Control) }\end{array}$ & $\begin{array}{c}100 \mathrm{ml} \text { NS without } 2 \text { units of syntocinon } \\
\text { infusion was continued at the rate of } 30 \text { to } 50 \\
\text { drops per minute. Immediately after } \\
\text { performing subarachnoid block. }\end{array}$ \\
\hline $\begin{array}{c}\text { Group SI } \\
(\mathrm{n}=100) \\
(\text { Test })\end{array}$ & $\begin{array}{c}100 \mathrm{ml} \text { NS with } 2 \text { units of syntocinon was } \\
\text { added and infusion was continued at the rate } \\
\text { of } 30 \text { to } 50 \text { drops per minute, immediately } \\
\text { after performing subarachnoid block. }\end{array}$ \\
\hline
\end{tabular}

\section{Preparation of Patients}

- All patients were uniformly premedicated with Inj. Ondansetron $4 \mathrm{mg}$ IV before surgery.

- Intradermal sensitivity test of Sensoricaine Hydrochloride was performed.

- Preloading of $500 \mathrm{ml}$ Ringer's lactate solution was started with $18 \mathrm{G}$ Cannula, before start of anaesthesia.

\begin{abstract}
Anaesthesia Technique
Baseline monitoring is done with ECG, pulse Oxymetry, Noninvasive blood pressure monitoring. Spinal anaesthesia was performed in sitting position at L3- L4 intervertebral space with 23G -25G Whitacare needle and $1.8 \mathrm{ml}$ of $(0.5$, bupivacaine Heavy spinal anaesthetic solution was given. After spinal anaesthesia in supine position wedge was kept for left lateral tilt, sensory level is optimized between T6- T8 was assessed by pinprick, first reading of ECG, saturation and blood pressure was recorded. 2 units of syntocinon ${ }^{4,5}$ was added with $100 \mathrm{ml}$ of NS solution and infusion was maintained as 30-40 drops per minute, $1 \mathrm{~min}, 2 \mathrm{~min}, 3 \mathrm{~min}, 5$ min parameter of ECG, saturation, blood pressure, blood pressure, uterine tonicity and newborn APGAR score were recorded, after delivery of baby 10 units syntocinon was given I.M and 10 units with remaining RL infusion, haematocrit value was measured preoperative and immediately after skin closure.
\end{abstract}

\section{Monitoring}

Baseline observations preoperatively were started before intrathecal drug injection. Pulse rate, electrocardiogram, systolic and diastolic BP, respiratory rate, peripheral arterial haemoglobin oxygen saturation, uterine contraction, blood loss \& baby Apgar score were monitored.

\section{Criteria for-}

(a) Bradycardia: a pulse rate of $60 / \mathrm{min}$ or less was treated by injection atropine/ glycopyrrolate IV.

(b) Hypotension: a fall in systolic BP $20 \%$ or greater from the base line value was treated by injection mephentermine IV, intravenous fluids (crystalloid, colloid and blood) as per requirement and oxygen by face mask.

(c) Respiratory Depression: a respiratory rate of less than 10 breaths per min or peripheral arterial haemoglobin oxygen saturation less than $85 \%$ was treated by oxygen supplementation through face mask.

\section{Statistical Analysis}

Demographic data and baseline measurements are presented as mean (SD) and group differences were tested using Chi square test and student $t$ test, respectively. The software used was Sigma Stat 3.5.

\section{RESULTS}

With syntocinon group we observed in syntocinon group perioperative haemodynamic stability (No fall in blood pressure and bradycardia), better uterine contraction, and minimal blood loss and there is no alteration in neonatal APGAR score in relation with patients with non syntocinon group.

\begin{tabular}{|c|c|c|}
\hline $\begin{array}{c}\text { Age Distribution } \\
\text { (In Years) }\end{array}$ & $\begin{array}{c}\text { Group NSI } \\
\text { (Control) }\end{array}$ & $\begin{array}{c}\text { Group SI } \\
\text { (Test) }\end{array}$ \\
\hline $20-25$ & 40 & 30 \\
\hline $25-30$ & 42 & 51 \\
\hline $30-35$ & 18 & 19 \\
\hline \multicolumn{3}{|c|}{} \\
\hline Table 1. Peri-Operative Monitors (Age, Parity, Weight, \\
Gestational Age and Peri-Operative HCT)
\end{tabular}

\section{Age Wise Distribution of Patients}

From our observation, Table No. 1 shows no significant difference in terms of AGE in Group SI compared with Group NSI. Hence the groups were comparable.

\begin{tabular}{|c|c|c|}
\hline Parity & Group NSI (Control) & Group SI (Test) \\
\hline G1 & 32 & 41 \\
\hline G2 & 50 & 43 \\
\hline G3 & 18 & 16 \\
\hline \multicolumn{3}{|c|}{ Table 2. Parity } \\
\hline \multicolumn{2}{|c|}{} \\
\hline
\end{tabular}

From our observation, Table No. 2 shows no significant difference in terms of PARITY in Group SI compared with Group NSI. Hence the groups were comparable.

\begin{tabular}{|c|c|c|}
\hline Preoperative HCT & Group NSI (Control) & Group SI (Test) \\
\hline $8-10 \mathrm{gm}$ & 34 & 37 \\
\hline $10-12 \mathrm{gm}$ & 52 & 57 \\
\hline above $12 \mathrm{gm}$ & 14 & 6 \\
\hline Total & $\mathbf{1 0 0}$ & $\mathbf{1 0 0}$ \\
\hline \multicolumn{2}{|c|}{ Table 3. Peri-Operative HCT } \\
\hline
\end{tabular}

From our observation, Table No. 3 shows no significant difference in terms of Preoperative HCT in Group SI compared with Group NSI. Hence the groups were comparable.

\begin{tabular}{|c|c|c|}
\hline & Group NSI (Control) & Group SI (Test) \\
\hline$<70 \mathrm{~mm}$ of $\mathrm{Hg}$ & 8 & 2 \\
\hline $70-90 \mathrm{~mm}$ of $\mathrm{Hg}$ & 12 & 72 \\
\hline $90-120 \mathrm{~mm}$ of $\mathrm{Hg}$ & 80 & 24 \\
\hline$>120 \mathrm{~mm}$ of $\mathrm{Hg}$ & 4 & 2 \\
\hline Total & 100 & 100 \\
\hline \multicolumn{3}{|c|}{ Table 4. HR, Saturation, Blood Pressure and Blood Loss } \\
\hline
\end{tabular}

From our observation, Table No. 4 shows significant difference in terms of Blood pressure in Group SI compared with Group NSI. $(\mathrm{p}<0.00001)$ 


\begin{tabular}{|c|c|c|}
\hline $\begin{array}{c}\text { Heart Rate } \\
\text { (in mins.) }\end{array}$ & $\begin{array}{c}\text { Group NSI } \\
\text { (Control) }\end{array}$ & $\begin{array}{c}\text { Group SI } \\
\text { (Test) }\end{array}$ \\
\hline $70-90$ & 18 & 62 \\
\hline $90-100$ & 70 & 22 \\
\hline $100-110$ & 12 & 16 \\
\hline $110-120$ & 6 & 0 \\
\hline Total & $\mathbf{1 0 0}$ & $\mathbf{1 0 0}$ \\
\hline \multicolumn{2}{|c|}{ Table 5. Pre-Operative HCT } \\
\hline
\end{tabular}

\begin{tabular}{|c|c|c|}
\hline Blood Loss (in ml) & Group NSI (Control) & Group SI (Test) \\
\hline Less than $300 \mathrm{ml}$ & 40 & 76 \\
\hline $300-450 \mathrm{ml}$ & 49 & 22 \\
\hline More than $450 \mathrm{ml}$ & 11 & 2 \\
\hline Total & $\mathbf{1 0 0}$ & $\mathbf{1 0 0}$ \\
\hline \multicolumn{3}{|c|}{ Table 6. Blood loss } \\
\hline
\end{tabular}

From our observation, Table No. 6 shows significant difference in terms of Blood Loss in Group SI compared with Group NSI. $(\mathrm{p}<0.00001)$

\begin{tabular}{|c|c|}
\hline & $\begin{array}{c}\text { Usage of Vasopressor/ } \\
\text { Glycopyrrolate }\end{array}$ \\
\hline Group NSI (Control) & 30 \\
\hline Group SI (Test) & 5 \\
\hline Table 7. Peri-Operative Volume Replacement and \\
Usage of Vasopressor
\end{tabular}

\begin{tabular}{|c|c|c|}
\hline Uterine Tonicity & Group NSI (Control) & Group SI (Test) \\
\hline Weak Contraction & 30 & 5 \\
\hline Good Contraction & 70 & 95 \\
\hline \multicolumn{2}{|c|}{ Table 8. Uterine Tonicity (2 min., 3 min., 5 min. and 10 } \\
mins.)
\end{tabular}

From our observation, Table No. 8 shows significant difference in terms of uterine tonicity in Group SI compared with Group NSI. $(\mathrm{p}<0.00001)$.

\begin{tabular}{|c|c|c|}
\hline APGAR Scoring & Group NSI (Control) & Group SI (Test) \\
\hline 1 minute & 8 & 8 \\
\hline 2 minutes & 9 & 9 \\
\hline 5 minutes & 9 & 9 \\
\hline 10 minutes & 10 & 10 \\
\hline \multicolumn{2}{|c|}{ Table 9. APGAR Scoring (1 min., 5 min. and 10 mins.) } \\
\hline
\end{tabular}

From our observation, Table No. 9 shows no significant difference in terms of APGAR in Group SI compared with Group NSI. Hence the groups were comparable.

\section{DISCUSSION}

Oxytocin is a nine-amino acid peptide that normally is produced in the hypothalamus and secreted by the posterior pituitary in a spurting or pulsatile fashion. During normal pregnancy, serum oxytocin concentrations increase slightly throughout gestation, and there is only modest increase in total serum concentrations before labour6. However, with labour, plasma levels increase significantly and then peak in the second stage. Expression of oxytocin receptors increase in the decidua and myometrium in the weeks preceding the onset of labour and increase sharply just before labour.7 Oxytocin receptors are expressed primarily in decidua, myometrium, and breast tissue. Myometrial sensitivity to oxytocin parallels expression of oxytocin receptors such that responsiveness begins at about 20 weeks' gestation and then dramatically increases at about 30 weeks' gestation. Oxytocin is cleared from peripheral blood by the liver and kidney and also is significantly metabolized by oxytocinase, an enzyme produced in abundant quantities by the placenta and gestational tissues.

$$
\begin{array}{|l}
\hline \text { Glu---Asp---Cys---Pro---Arg---Gly } \\
\text { I } \\
\text { Ile---Tyr---Cys }
\end{array}
$$

The myometrial response to oxytocin is highly variable 8 , and uterine hyperstimulation may occur at any dose of administered oxtocin ${ }^{9}$, depending on the patient. A randomized study by Xenakis and co-workers compared the low dose protocol of Seitchik ${ }^{10}$ to a higher dose protocol and there were no differences in maternal or neonatal outcome or in the incidence of hyperstimulation. ${ }^{11}$

It is well known that oxytocin produces uterine activity when administered to pregnant women. The role of endogenous oxytocin as an initiator of term or preterm labour is less well defined. Some reasons to suspect that oxytocin is a universal initiator of labour are its ability to induce labour. The number of myometrial cell membrane oxytocin receptors greatly increases as pregnancy advances, with a further increase during labour itself.

As we all know that giving spinal anaesthesia and conducting anaesthesia for elective as well as emergency LSCS is more challenging, starting from brief discussion about spinal anaesthesia, haemodynamic stability, control of uterine bleeding and better neonatal outcome. In that we consider of giving perioperative syntocinon infusion 2 units $^{12,13}$ in $100 \mathrm{ml}$ NS (before the uterine incision ${ }^{14}$ and delivery of the baby) as a priming technique to augment uterine contractions 15 and from our observation it is found to be more beneficial in maintaining haemodynamic stability 16 without much usage of inj. phenyl ephedrine and inj. glycopyrrolate. Good uterine contractions, minimal uterine blood loss in comparison with usual dose of syntocinon without alteration in APGAR scoring are noted.17,18

From our observation, Table No. 8 shows significant difference in terms of uterine tonicity in Group SI compared with Group NSI. $(\mathrm{p}<0.00001)$.

\section{CONCLUSION}

Pre-uterine-incision (before delivery of the baby) syntocinon infusion is very much useful in maintaining haemodynamic stability, leads to better uterine contractions, minimises blood loss, without altering neonatal outcome and so is beneficial for patients, anaesthesiologists as well as surgeons.

\section{REFERENCES}

[1] Walsh J, Foley M, O'Herlihy C. Dystocia correlates with body mass index in both spontaneous and induced nulliparous labours. J Matern Fetal Neonatal Med 2011;24(6):817-21.

[2] Marcus HE, Fabian A, Lier H, et al. Survey on the use of oxytocin for caesarean section. Minerva Anestesiol 2010;76(11):890-5.

[3] Butwick AJ, Coleman L, Cohen SE, et al. Minimum effective bolus dose of oxytocin during elective Caesarean delivery. Br J Anaesth 2010;104(3):338-43.

[4] Carvalho JC, Balki M, Kingdom J, et al. Oxytocin requirements at elective Cesarean delivery: a dose- 
finding study. Obstet Gynecol 2004;104(5 Pt 1):100510.

[5] Thomas JS, Koh SH, Cooper GM. Haemodynamic effects of oxytocin given as i.v. bolus or infusion on women undergoing Caesarean section. $\mathrm{Br} \mathrm{J}$ Anaesth 2007;98(1):116-9.

[6] Devikarani D, Harsoor S. Are we using right dose of oxytocin? Indian J Anaesth 2010;54(5):371-3.

[7] Clark SL, Simpson KR, Knox GE, et al. Oxytocin: new perspectives on an old drug. Am J Obstet Gynecol 2009;200(1):35.e1-6.

[8] Prasad MR, Funai E. Oxytocin use during active labour: too much of a good thing? American Journal of Obstetrics and Gynecology 2012;207(6):439-40.

[9] George RB, McKeen D, Chaplin AC, et al. Up-down determination of the ED (90) of oxytocin infusions for the prevention of postpartum uterine atony in parturient undergoing. Cesarean delivery. Can J Anaesth 2010;57(6):578-82.

[10] Seitchik J, Castillo M. Oxytocin augmentation of dysfunctional labour. I. Clinical data. Am J Obstet Gynecol 1982;144(8):899-905.

[11] Pinder AJ, Dresner M, Calow C, et al. Haemodynamic changes caused by oxytocin during caesarean section under spinal anaesthesia. Int J Obstet Anesth 2002;11(3):156-9.

[12] Sartain JB, Barry JJ, Howat PW, et al. Intravenous oxytocin bolus of 2 units is superior to 5 units during elective Caesarean section. $\mathrm{Br} \mathrm{J}$ Anaesth 2008;101(6):822-6.
[13] Wei SQ, Luo ZC, Qi HP, et al. High-dose vs low-dose oxytocin for labour augmentation: a systematic review. Am J Obstet Gynecol 2010;203(4):296-304.

[14] Abdelaleem AA, Abbas AM, Thabet AL, et al. The effect of initiating intravenous oxytocin infusion before uterine incision on the blood loss during elective Cesarean section: a randomized clinical trial. The Journal of Maternal Fetal \& Neonatal Medicine 2018:16.

[15] Wedisinghe L, Macleod M, Murphy DJ. Use of oxytocin to prevent haemorrhage at Caesarean section-a survey of practice in the United Kingdom. Eur J Obstet Gynecol Reprod Biol 2008;137(1):27-30.

[16] Al-Zirqi I, Vangen S, Forsen L, et al. Prevalence and risk factors of severe obstetric haemorrhage. BJOG 2008;115(10):1265-72.

[17] Kotaska AJ, Klein MC, Liston RM. Epidural analgesia associated with low dose oxytocin augmentation increases Cesarean births: a critical look at external validity of randomized trails. Am J Obstet Gynecol 2006;194(3):809-14.

[18] Simpson KR, James DC. Effects of oxytocin-induced uterine hyperstimulation during labour on fetal oxygen status and fetal heart rate patterns. American Journal of Obstetrics \& Gynecology 2008;199(1):34.e1-5. 